\title{
HUBUNGAN SHIFT KERJA DENGAN KELELAHAN KERJA PADA PERAWAT DI BANGSAL RAWAT INAP RUMAH SAKIT ADVENT BANDAR LAMPUNG
}

\author{
${ }^{1}$ Nursehan Br Ginting, ${ }^{2}$ Evelin Malinti \\ ${ }^{1}$ Rumah Sakit Advent Bandar Lampung, Jl Teuku umar no 48 Bandar lampung \\ ${ }^{2}$ Fakultas Ilmu Keperawatan Universitas Advent Indonesia Jl. Kolonel Masturi no 288, Cihanjuang Rahayu \\ E-mail: gintingnursehan@gmail.com
}

\begin{abstract}
Abstrak
Pendahuluan: Rumah sakit merupakan pelayanan kesehatan yang beroperasi selama 1x24 jam dan menyediakan perawatan rawat inap selama 3 shift. Beban kerja perawat cukup tinggi sehingga tingkat kelelahan perawat berbedabeda setiap shifnya. Tujuan: Untuk mengetahui hubungan antara shift kerja dengan kelelahan kerja perawat di bangsal rawat inap Rumah Sakit Advent Bandar Lampung. Metode: Metode penelitian ialah deskriptif korelasi dengan pendekatan cross sectional study dan pengambilam sampel menggunakan teknik purposive sampling. Pengumpulan data menggunakan kuesioner kelelahan kerja yang diberikan kepada perawat rawat inap dan di analisa dengan ChiSquare test Hasil: Hasil uji Analisa statistik didapati nilai $p=0,683>0,05$ berarti tidak ada hubungan yang signifikan antara shift kerja dengan kelelahan. Rekomendasi: Peneliti selanjutnya sebaiknya membandingkan tingkat kelelahan dari berbagai departemen dan perhatikan modiabel variabel seperti usia, jenis kelamin dan status menikah. Implikasi: Adanya penelitian ini diharapkan tingkat kelelahan perawat dapat diketahui, juga menjadi acuan pihak management tetap memperhatikan tingkat kelelahan perawat.
\end{abstract}

Kata Kunci: Kelelahan kerja, shift kerja

\section{Abstract}

Introduction: The hospital is a health service that operates for $1 \times 24$ hours and provides inpatient care for 3 shifts. The workload of nurses is quite high so that the level of nurse fatigue is different for each shift. Objective: To determine the relationship between work shifts and work fatigue of nurses in the inpatient ward of the Bandar Lampung Adventist Hospital. Method: This research used a descriptive correlation with a cross sectional study approach and the sample is taken using a purposive sampling technique. Collecting data using a work fatigue questionnaire given to inpatient nurses and analyzed with the Chi-Square test. Results: The results of the statistical analysis test showed that the value of $p=0,683>0,05$ means that there is no significant relationship between work shifts and fatigue.. Recommendation: The next researcher should compare the level of fatigue across various departments and consider several variables such as age, sex, and marital status. Implication: The existence of this research is expected that the level of fatigue of nurses can be known, as well as a reference for management to pay attention to the fatigue level of nurses.

Keywords: Work fatigue, shift work

\section{Pendahuluan}

Bidang jasa yang memegang peranan cukup penting untuk memenuhi kepuasan pelayanan kesehatan masyarakat adalah pelayanan dari rumah sakit (Hadijah, 2016). Berdasarkan Undang- Undang No 44 Tahun 2009 tentang Rumah Sakit, yang dimaksudkan dengan rumah sakit adalah institusi pelayanan kesehatan yang menyelenggarakan pelayanan kesehatan perorangan secara paripurna dan menyediakan pelayan rawat inap, rawat jalan, dan gawat darurat (Nugroho, 2019).

Rumah sakit perlu memenuhi beberapa persyaratan dalam melaksanakan pelayanan kesehatan salah satunya ialah tersedianya sumber daya manusia. Tenaga perawat adalah salah satu yang berperan penting dalam pemberian pelayanan yang bermutu juga aman karena 
akan berdampak pada kepuasan, kenyamanan dan kesembuhan pasien (Romadhoni \& Pudjirahardhjo, 2016).

Perawat menanggung beban kerja yang cukup tinggi dalam melaksanakan tanggung jawab pelayanan keperawatan yang efektif (Maramis dan Kandowangko, 2019). Terkait dengan gangguan kesehatan perawat dan kesejahteraan, kelelahan biasanya dilaporkan diantara pekerja dengan tingkat kelelahan yang lebih tinggi umumnya terjadi pada pekerjaan dengan penjadwalan kerja, bekerja lebih lama, juga jam dan waktu pemulihan tidak mencukupi (Gifkins, Johnston, Loudoun, dan Troth (2020).

Menurut World Health Organization (WHO) dalam model kesehatan yang dibuat sampai pada tahun 2020 diramalkan bahwa gangguan psikis berupa perasaan lelah yang berat dan berujung pada depresi akan menjadi penyakit pembunuh nomor dua setelah penyakit jantung (Munandar, Permatasari, dan Rezal, 2017). Data dari International Labour Organization (ILO) menunjukkan bahwa hampir setiap tahun sebanyak dua juta pekerja meninggal dunia karena kecelakaan kerja yang disebabkan oleh faktor kelelahan (Karbito \& Oksandi, 2020). Pada laporan survei 2018 oleh National Safety Concil (NSC), dua pertiga angkatan kerja AS mengalami kelelahan di tempat kerja yang berarti, hampir 107 juta dari 160 juta pekerja AS terkena kelelahan kerja (Muller, 2020). Penelitian yang dilakukan oleh Kementerian Tenaga Kerja Jepang terhadap 12.000 perusahaan yang melibatkan sekitar 16.000 pekerja yang dipilih secara acak menunjukkan bahwa $65 \%$ pekerja mengeluhkan kelelahan fisik akibat kerja rutin, 28\% mengeluhkan kelelahan mental dan sekitar 7\% pekerja mengeluh stress berat dan merasa tersisihkan (Munandar, Permatasari, \& Rezal, 2017).

Departemen Tenaga Kerja pada tahun 2014 menjelaskan bahwa data mengenai kecelakaan kerja di Indonesia setiap hari rata-rata terjadi 414 kecelakaan kerja, dan $27,8 \%$ disebabkan kelelahan yang cukup tinggi (Mualin \& Yusmidiarti, 2019). The Joint Comission di tahun 2008 melaporkan bahwa ada $300 \%$ lebih perawat membuat kesalahan karena kelelahan dan berujung kepada kematian pasien (Muis, Mulfiyanti, \& Rivai, 2019).

Faktor-faktor yang berpengaruh terhadap terjadinya kelelahan kerja diantaranya lingkungan, usia, beban kerja, masa kerja dan lama bekerja Oksandi dan (Karbito, 2020). Rumah sakit yang menyediakan pelayanan rawat inap mengharuskan adanya pengaturan shift kerja agar pelayanan kesehatan dapat terus diberikan kepada semua pasien (Nur, 2019). Adanya aturan waktu kerja, maka proses kerja tidak dapat berhenti, oleh sebab itu diaturlah pembagian waktu kerja bagi karyawan atau pegawai dengan shift kerja (Nur, 2019).
Peraturan Kemenkes pada tahun 2013 ditetapkan bahwa periode kerja dibagi 3, yaitu periode pagi sampai sore, periode sore sampai malam dan berkerja pada periode malam sampai pagi (Nur, 2019). Waktu kerja sebaiknya 7 jam kerja per hari atau 40 jam kerja per minggu untuk 6 hari kerja dalam seminggu dan 8 jam kerja per hari atau 40 jam kerja per minggu untuk 5 hari kerja dalam 1 minggu (Julia, 2017). Maksimum waktu kerja tambahan yang efisien ialah 30 menit, dan bila lebih dari ketentuan tersebut maka dapat terjadi penurunan kecepatan kerja, angka absensi meningkat karena terjadinya gangguan kesehatan dan dapat mengarah pada rendahnya produktivitas kerja Nur (2019).

Hasil penelitian yang sudah dilakukan di instalasi rawat inap di RS Herna Medan tahun 2018 disimpulkan bahwa terdapat hubungan shift kerja dengan kelelahan kerja pada perawat rawat inap di RS Herna Medan dengan tingkat kelelahan yang paling tinggi terdapat pada perawat shift malam 14 orang dan tingkat kelelahan terendah pada perawat shift pagi 2 orang (Nur, 2019).

Dengan demikian, melalui studi awal yang telah dilakukan melalui observasi dan wawancara kepada perawat di bangsal rawat inap didapati pengeluhan kelelahan dari masing-masing shift per hari, maka peneliti tertarik melakukan penelitian yang bertujuan mengetahui hubungan shift kerja dengan kelelahan kerja pada perawat di bangsal rawat inap Rumah Sakit Advent Bandar Lampung.

\section{Metode Penelitian}

Penelitian ini menggunakan desain penelitian deskriptif korelasi dengan pendekatan cross sectional, yaitu peneliti mengumpulkan data dari beberapa responden pada satu titik waktu tertentu (Hayati, 2020).

Responden dalam penelitian ini adalah perawat ruang rawat inap di Rumah Sakit Advent Bandar Lampung. Jumlah responden dalam penelitian ini merupakan total sampel dari perawat di ruang bangsal rawat inap yang berjumlah 75 perawat. Teknik pengambilan sampel juga menggunakan purposive sampling digunakan untuk menentukan kriteria inklusi, yaitu perawat di ruang bangsal rawat inap, bersedia menjadi responden, dan bersedia mengisi kuesioner. Sedangkan kriteria eksklusinya ialah perawat di ruang isolasi, di ruang instalasi rawat jalan, perawat di Intensive Care Unit (ICU), dan di Instalasi Gawat Darurat (IGD).

Instrumen yang digunakan ialah menggunakan kuesioner kelelahan kerja yang diadopsi dari Arnani (2019) dimana kuesioner dinyatakan valid bila hasil uji reliabilitas nilai cronbach alpha adalah sebesar 0,920 yang berarti lebih besar dari nilai $r$-tabel $=0,333$, sehingga instrumen penelitian dinyatakan reliabel. Jumlah pertanyaan sebanyak 30 butir, dinilai menggunakan skala Likert dimana 0: Tidak Pernah, 1: 
Kadang-kadang, 2: Sering dan 3: Sangat Sering. Dimana kuesioner dibagikan kepada perawat pada setiap shift kerja yang dibagi atas 3 shift, yaitu shift pagi, shift sore dan shift malam (Suoth, 2020).

Analisa data dilakukan dengan mencari distribusi frekuensi dan dilakukan uji hubungan dengan chi square test.

\section{Hasil}

Tabel 1. Hasil deskriptif karakteristik perawat rawat inap di Rumah Sakit Advent Bandar Lampung

\begin{tabular}{lll}
\hline Kategori & $\mathrm{F}$ & Persentase \% \\
\hline Usia & & \\
\hline$<40$ tahun & 53 & 70.7 \\
$\geq 40$ tahun & 22 & 29.3 \\
\hline Status & & \\
\hline Belum menikah & 30 & 40 \\
Menikah & 45 & 60 \\
\hline Shift Kerja & & \\
\hline Pagi & 25 & 33.3 \\
Sore & 25 & 33.3 \\
Malam & 25 & 33.3 \\
\hline Tingkat Kelelahan & & \\
\hline Tidak Lelah & 43 & 57,3 \\
Lelah & 32 & 42,7 \\
\hline
\end{tabular}

Berdasarkan tabel 1, diketahui dari 75 responden, mayoritas perawat berusia $<40$ tahun yaitu sebanyak $70,7 \%$ (53 perawat). Perawat dengan status menikah lebih banyak dibandingkan dengan yang belum menikah, yaitu 60\% (45 perawat). Didapati pembagian jumlah perawat per shift, yaitu 25 perawat dari masingmasing shift. Tingkat kelelahan perawat didapati lebih dari setengah merasa tidak lelah yaitu sebanyak $57,3 \%$ (43 perawat).

Tabel 2. Hasil uji hubungan shift kerja dengan kelelahan kerja pada perawat di bangsal rawat inap Rumah Sakit Advent Bandar Lampung

\begin{tabular}{lccc}
\hline \multirow{2}{*}{ Shift } & \multicolumn{2}{c}{ Tingkat Kelelahan } & \multirow{2}{*}{ P value } \\
\cline { 2 - 3 } & Tidak lelah & Lelah & \\
\hline Pagi & 16 & 9 & .683 \\
Sore & 14 & 11 & \\
Malam & 13 & 12 & \\
\hline
\end{tabular}

Hasil yang didapati berdasarkan pada table 5, nilai $p=0,683$ dimana $p>0,05$ artinya $\mathrm{H} 1$ ditolak dan $\mathrm{H} 0$ diterima yang berarti menunjukkan tidak adanya hubungan yang signifikan antara shift kerja dengan kelelahan kerja.

\section{Pembahasan}

Hasil deskriptif usia menunjukkan sebagian besar perawat berusia kurang dari 40 tahun sebanyak 70,7\% (53 perawat). Hasil penelitian ini sejalan dengan hasil yang didapatkan oleh Magdalena dan Rhamdani (2019) dimana paling banyak perawat berusia kurang dari atau sama dengan 40 tahun yang bekerja di RSUD Asy-Syifa Sumbawa Barat.

Didapatkan hasil deskriptif status pernikahan pada perawat ruang rawat inap di Rumah Sakit Advent Bandar Lampung ialah lebih banyak perawat yang telah menikah sebanyak $60 \%$ (45 perawat). Hasil penelitian Magdalena dan Rhamdani (2019) juga mendapati lebih dari setengah perawat telah menikah yaitu sebanyak 52\% (53 perawat). Begitupula pada penelitian yang dilakukan di Rumah Sakit Badung dan Kabupaten Denpasar, Bali, Indonesia didapati lebih banyak perawat memiliki status menikah, yaitu 56,9\% (58 perawat) (Juniartha, Kartika, \& Sadjono, 2018).

Secara keseluruhan hasil deskriptif tingkat kelelahan didapati dari 75 perawat paling banyak perawat berada pada tingkat tidak lelah, uaitu sebanyak 57,3\% (43 perawat). Berbeda dengan penelitian yang dilakukan oleh Herlina dan Kondi (2019) dimana 31 perawat $(51,7 \%)$ mengalami kelelahan kerja. Berbanding terbalik juga dengan penelitian yang dilakukan di RSUD AsySyifa Sumbawa Barat didapati bahwa lebih banyak perawat yang merasa lelah yaitu sebanyak 46 perawat $(45,1 \%)$.

Dari hasil wawancara dan melalui pengisian kuesioner didapati keluhan kelelahan kerja sangat kurang karena lebih dari setengah perawat merasa bahwa pembagian waktu kerja dan istirahat yang dirasakan diatur dengan baik oleh pihak managemen dan juga merasa memiliki lingkungan kerja yang nyaman.

Kelelahan dapat berkembang setelah aktivitas kerja apa pun dan dapat pulih setelah istirahat atau istirahat yang cukup (Gifkins, Johnston, Loudoun, \& Troth, 2020). Lingkungan kerja yang nyaman, aman, tenang, sarana dan prasarana yang baik, waktu kerja yang cukup, pembagian shift maupun pelimpahan tugas dan tanggung jawab yang sesuai mampu membantu mengurangi kejenuhan dan kelelahan untuk perawat (Noviyanti \& Supriyadi, 2020).

Hasil yang didapati berdasarkan pada table 2, nilai $p=0,683$ dimana $p>0,05$ artinya $\mathrm{H} 1$ ditolak dan $\mathrm{H} 0$ diterima yang menunjukkan tidak adanya hubungan yang signifikan antara shift kerja dengan kelelahan kerja. Hasil penelitian ini Sama dengan hasil penelitian Maghfiroh dan Mifbakhuddin (2015) yang dilakukan pada 34 perawat yang mendapati bahwa tidak ada hubungan yang signifikan antara shift kerja dengan kelelahan. Berbanding terbalik dengan hasil penelitian yang dilakukan oleh Nur (2019) didapati nilai $p=0,016<0,05$ yang menunjukkan ada hubungan yang sangat signifikan antara shift kerja dengan kelelahan.

Mencegah kelelahan dan mengurangi efek sampingmembutuhkan kesadaran yang komprehensif tentang beragam faktor penyebabnya (Alahmadi \& 
Alharbi, 2018). Faktor-faktor yang dapat menyebabkan kelelahan diantaranya ialah lingkungan kerja, riwayat penyakit, beban kerja, sifat pekerjaan, shift kerja, faktor individu, dan faktor psikologis (Ihsan \& Salami, 2020).

Selain itu, aktivitas yang dianggap mencirikan kelelahan kerja antara pekerja shift medis yang berdiri lebih dari 6 jam, membungkuk lebih dari 10 kali per jam, dan bangun sepanjang malam pada jam shift malam (Andarini, Arifah, \& Dianita, 2019).

Disisi lain, pasien dan tindakan yang diberikan menentukan beban kerja perawat. Semakin banyak dan rumitnya tindakan maka beban kerja meningkat (Maghfiroh \& Mifbakhuddin, 2015). Tingkat beban kerja yang berlebih dapat menyebabkan terjadinya kelelahan kerja (Agustinawati, Dinata, \& Primayanti, 2019).Hasil yang didapatkan dalam penelitian ini didapati bahwa perbedaan jumlah pasien yang dirawat pada setiap shift tidak terlalu signifikan, sehingga memungkinkan kelelahan perawat pada setiap nya berada pada tingkat yang sama.

\section{Kesimpulan}

Berdasarkan hasil uji analisa data tentang hubungan shift kerja dengan kelelahan kerja pada perawat di bangsal rawat inap rumah sakit Advent Bandar Lampung didapatkan kesimpulan bahwa tidak terdapat hubungan yang signifikan antara shift kerja degan kelelahan kerja dengan didapatinya nilai $p=0,683$ atau $p>0,05$.

Diharapkan peneliti selanjutnya untuk membandingkan tingkat kelelahan dari berbagai departemen dengan memperhatikan berbagai modiabel variable seperti usia, jenis kelamin dan status menikah.

\section{References}

Agustinawati, K., Dinata, I., \& Primayanti, I. (2019). Hubungan antara Beban Kerja dengan Kelelahan Kerja dengan Kelelahan Kerja pada Pengrajin Industri Bokor di Desa Menyali. Jurnal Medika Udayana, Vol. 9 No. 9.

Alahmadi, A., \& Alharbi, M. (2018). Work-Related Fatigue Factors among Hospital Nurses: An Integrative Literature Review. Nurse Media Journal of Nursing, 8(2), 113-133.

Andarini, Y., Arifah, D., \& Dianita, R. (2019). Occupational Fatigue Based on Work Shift Among Medical Workers at DR Harjno Hospital. Jurnal Ilmu Kesehatan Masyarakat, 10 (3), 199-206.

Arnani, H. (2019). Perbedaan Kelelahan Kerja pada Shift Pagi dan Shift Malam Karyawan Bagian
Produksi di Pabrik Teh PTPN IV Bah Butong.

Sumatera Utara: Universitas Islam Negeri.

Gifkins, J., Johnston, A., Loudoun, A., \& Troth, A. (2020). Fatigue and Recovery in Shiftworking Nurses: A Scoping Literature Review.

International Journal of Nursing Studies 112, $1-15$.

Hadijah. (2016). Analis Kualitas Pelayanan Rawat Inap di Rumah Sakit Umum Daerah Undata Palu Provinsi Sulawesi Tengah. Jurnal Katalogis, Volume 4 Nomor 7, 118-129.

Hayati, R. (2020, Desember 1). Pengertian Cross Sectional, Kelebihan, Kekurangan, dan Contohnya. Retrieved from PenelitianIlmiah.Com: penelitianilmiah.com/cross-sectional

Herlina, \& Kondi, A. (2019). Faktor-Faktor yang Berhubungan dengan Kelelahan Kerja pada Perawat di Rumah Sakit Awal Bross Bekasi. Jurnal Persada Husada Indonesia, Vol. 6 No. 20, 1-9.

Ihsan, T., \& Salami, I. (2020). Fatigue in Shift Work on Stamping Division Workers of PT. Toyota Motor Manufacturing Indonesia. KEMAS, 15 (3), 316-323.

Julia, L. (2017). Jam Kerja, Cuti dan Upah. Jakarta: International Labour Organization.

Juniartha, I., Kartika, D., \& Sadjono, T. (2018). Different Effect of Shift Work on Fatigue and Work Related Stress in Emergency Room Nurses at the Hospitals In Badung and Denpasar Regency, Bali, Indonesia. Public Health of Indonesia, 4(2), 57-66.

Karbito, A., \& Oksandi, H. (2020). Faktor-Faktor yang Berhubungan dengan Kelelahan Kerja pada Perawat di RSUD dr. H. BOB Bazar Kalianda Kabupaten Lampung Selatan. Jurnal Ilmu Kesehatan Indonesia (JIKSI), Vol. 1 No. 1, 1-7.

Magdalena, W., \& Rhamdani, I. (2019). Hubungan anatara Shift Kerja, Kelelahan kerja dengan Stres Kerja pada Perawat. Jurnal Biomedika dan Kesehatan, Vol. 2, No. 3, 104-110.

Maghfiroh, S., \& Mifbakhuddin. (2015). Hubungan Toleransi Stres, Shift Kerja dan Status Gizi dengan Kelelahan pada Perawat IGD dan ICU. J. Kesehatan Masyarakat Indonesia, 10(2), 4653. 
Maramis, J., \& Kandowangko, C. (2019). Hubungan Burnout dan Keluhan Nyeri Muskuloskeletal pada Mahasiswa Profesi Ners di Universitas Klabat. Jurnal Skolastik Keperawatan, Vol 5, No. 2, 155-164.

Mualin, \& Yusmidiarti. (2019). Hubungan Ergonomi dan Psikososial dengan Kelelahan Kerja pada Tenaga Kerja Perusahaan Dagang Sinar Harapan Teknik di Padang Serai KOta Bengkulu. Journal of Health Science, Vol. 11 No. 2.

Muller, J. (2020). Workolace Fatigue Statictics and its Staggerig Cost. Ergonomic Trends.

Munandar, S., Permatasari, A., \& Rezal, F. (2017). Faktor yang Berhubungan dengan Kelelahan Kerja pada Karyawan di Matahari Departement Store Cabang Lippo Plaza Kendari Tahun 2016. Jurnal Ilmiah Mahasiswa Kesehatan Masyarakat, Vol 2/No. 5, 1-11.

Noviyanti, I., \& Supriyadi. (2020). Hubungan Kondisi Kerja dengan Kelelahan Kronis pada Perawat di
Ruang Rawat Inap RSUD Wonosari. Jurnal Keperawatan, Vol. 12, No. 2, 71-79.

Nugroho, A. (2019, Desember 04). Rumah Sakit yang Sakit. Retrieved from Jawa Pos: Radar Kediri: radarkediri.jawapos.com

Nur. (2019). Hubungan Shift Kerja dengan Kelelahan Kerja pada Perawat di Instalasi Rawat Inap di Rumah Sakit Herna Medan Tahun 2018. Jurnal JUMANTIK, Vol. 4, No. 1, 45-56.

Romadhoni, R., \& Pudjirahardhjo, W. (2016). Beban Kerja Obyektif Tenaga Perawat di Pelayanan Rawat Inap Rumah Sakit. Jurnal Administrasi Kesehatan Indonesia, Volume 4 Nomor 1, 57 56.

Suoth, C. (2020). Peraturan Perusahaan: Rumah Sakit Advent. Bandar Lampung: Rumah Sakit Advent. 